\title{
Lipoprotein lipase Pvull polymorphism is associated with variations in serum lipid levels in non-diabetic pregnant women
}

R.J.C. Sepetiba ${ }^{1}$, J. Andrade ${ }^{2,4}$, R.D.C. Hirata ${ }^{3}$, M.H. Hirata ${ }^{3}$,

C.R.G. Sepetiba ${ }^{4}$, Y. Nakamura ${ }^{4}$

L.O. Matsumoto ${ }^{3}$ S.A. Cavalli ${ }^{3}$ and M.C. Bertolami ${ }^{4}$

\author{
${ }^{1}$ Instituto do Coração, Faculdade de Medicina, \\ ${ }^{2}$ Faculdade de Saúde Publica, \\ ${ }^{3}$ Faculdade de Ciências Farmacêuticas, \\ Universidade de São Paulo, São Paulo, SP, Brasil \\ ${ }^{4}$ Instituto Dante Pazzanese de Cardiologia, São Paulo, SP, Brasil
}

Correspondence

M.C. Bertolami

Av. Sabiá, 667, Apto. 141

04515-001 São Paulo, SP

Brasil

Fax: +55-11-5549-4205

E-mail: bertolami@uol.com.br

Publication supported by FAPESP.

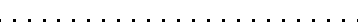

Received August 18, 2006 Accepted March 2, 2007

\section{Abstract}

The aim of the present study was to determine if there is an association between the single nucleotide polymorphisms (SNPs) of the lipoprotein lipase (LPL) and apolipoprotein E (apo E) genes and the serum lipid profile in pregnancy and puerperium. Non-diabetic women of European descent in the third semester of pregnancy $(\mathrm{N}=120)$ were selected. Those with diseases or other condition that could modify their lipid profile were excluded from the study $(\mathrm{N}=32)$. Serum lipids were measured by routine laboratory procedures and genomic DNA was extracted by a salting out method. LPL (PvuII and HindIII) and apo E (HhaI) SNPs were detected by the polymerase chain reaction and restriction fragment length polymorphism. Categorical and continuous variables were compared by the chi-square test and Student $t$ test or ANOVA, respectively. Women carrying the LPL P1P1 genotype had higher serum LDL cholesterol $(\mathrm{N}=21 ; 155 \pm 45 \mathrm{mg} / \mathrm{dL})$ than women carrying the P1P2/P2P2 genotypes $(\mathrm{N}=67 ; 133 \pm 45 \mathrm{mg} / \mathrm{dL}$; $\mathrm{P}=0.032$ ). During the puerperium period, serum levels of triglycerides and VLDL cholesterol were significantly reduced in women carrying the $\mathrm{P} 1 \mathrm{P} 1(73 \%, \mathrm{P}=0.006)$ and $\mathrm{P} 1 \mathrm{P} 2(51 \%, \mathrm{P}=0.002)$ genotypes but not in women carrying the $\mathrm{P} 2 \mathrm{P} 2$ genotype $(23 \%, \mathrm{P}>$ $0.05)$. On the other hand, serum concentrations of lipids did not differ between the LPL HindIII and apo E genotypes during pregnancy and after delivery. We conclude that LPL PvuII SNP is associated with variations in serum lipids during pregnancy and the puerperal period in non-diabetic women.
Key words

- Lipoprotein lipase

- LPL Pvull polymorphism

- Apolipoprotein E

- Single nucleotide

polymorphism

- Serum lipids

- Non-diabetic pregnancy 


\section{Introduction}

Lipoprotein lipase (LPL) is a glycoprotein synthesized by several tissues and cell types, including adipose, cardiac and skeletal tissues (1). LPL hydrolyzes triglycerides (TG) of circulating very low-density lipoproteins (VLDL) and chylomicrons, and generates fatty acids for storage in adipose tissue (1). During this process, these TGrich lipoproteins are converted to remnant particles which are removed from the circulation by interaction of apolipoproteins $\mathrm{E}$ (apo E) and B with specific receptors in the liver.

Structural and functional alterations of LPL and apo E can cause reduction of TG hydrolysis and removal of TG-rich lipoproteins from plasma, leading to hypertriglyceridemia (HTG) (1). Two common variants (PvuII and HindIII) of the LPL gene have been associated with variations of TG and cholesterol levels in plasma, cardiovascular diseases and acute myocardial infarction in Caucasian populations (2-7). In addition, the apo E gene has an HhaI single nucleotide polymorphism (SNP) that encodes three apo E isoforms named E2, E3 and E4 (8). These apo $\mathrm{E}$ isoforms interact with $\mathrm{B} / \mathrm{E}$ and $\mathrm{E}$ receptors with different affinities that affect the removal of apo E-rich lipoproteins, VLDL and chylomicron remnants, and contribute to TG and cholesterol elevation in plasma (8).

HTG is the most remarkable lipid alteration found in the third trimester of pregnancy. During this period, hepatic production of TG is increased and the clearance of VLDL is reduced probably due to the lower activity of LPL in adipose tissue $(9,10)$. Severe HTG can be developed in the late stages of pregnancy as a consequence of several factors such as diabetes, alcohol consumption or weight gain (10).

LPL mutations have been associated with extremely high TG levels and may be a common cause of pancreatitis associated with pregnancy $(11,12)$. It has been suggested that this abnormality in serum lipid levels is caused by LPL mutations in combination with apo E2 $(13,14)$. However, the contribution of common variants of the LPL and apo E genes to the variations in serum lipids during pregnancy remains to be elucidated.

The aim of the present study was to investigate the effects of LPL and apo E SNPs on serum lipids of non-diabetic women in the third trimester of pregnancy and during the puerperium period.

\section{Material and Methods}

\section{Subjects and study protocol}

A group of 120 unrelated non-diabetic women (18 to 36 years old) of European descent who were assisted during pregnancy by public services of the Metropolitan Health Department of São Paulo city were selected from September 2002 to March 2003. The women were evaluated during the third trimester of pregnancy and the puerperal period (up to 6 weeks after delivery). Pregnant women with heart, liver, kidney, thyroid or vascular diseases, hypertension, or taking medication that could influence their lipid profile $(\mathrm{N}=32)$ were excluded from the study. All women reported a normal glucose tolerance test.

The Ethics Committees of the Medical School of the University of São Paulo, Dante Pazzanese Institute of Cardiology, and Metropolitan Health Department (São Paulo, SP, Brazil) approved the protocol and written informed consent was obtained from the 88 women included in the study.

All women filled out a questionnaire with information about personal clinical history and family antecedents. Age, height, weight gain (currently and prior to pregnancy), previous number of pregnancies, diets, alcohol consumption, smoking, and any relevant information on current or previous medical history were also recorded. Gestational age 
was determined by ultrasonography.

\section{Laboratory analyses}

Blood samples were collected after a overnight 12-h fast for analysis of the serum lipid profile and other laboratory tests. Triglycerides, total cholesterol and high-density lipoprotein (HDL) cholesterol were measured by standard enzymatic methods using a $\mathrm{Hi}-$ tachi 912 auto-analyzer (Hitachi Ltd., Tokyo, Japan). VLDL cholesterol and lowdensity lipoprotein (LDL) cholesterol were calculated by the Friedewald formula. Plasma glucose and serum creatinine, urea, alanine and aspartate aminotransferases, gamma-glutamyl transpeptidase, and thyroidstimulating hormone were also determined.

\section{Genomic DNA analysis}

Genomic DNA was extracted from blood leukocytes by a salting out method (15). $P v u I I$ (intron 6) and HindIII (intron 8) SNPs of the LPL gene and the HhaI (exon 4) polymorphic region of the apo E gene were analyzed by the polymerase chain reaction (PCR) and restriction fragment length polymorphism as previously described $(16,17)$.

PCR assays were performed with $200 \mathrm{ng}$ DNA, $200 \mu \mathrm{M}$ deoxynucleotides (Amersham Pharmacia Biotech of Brazil, São Paulo, SP, Brazil), 10 pmol primers (Life Technologies Inc., Gaithersburg, MD, USA), 1.0 U DNA polymerase (Biotools B\&M Labs, Madrid, Spain), and amplification buffer $(50 \mathrm{mM}$ $\mathrm{KCl}, 20 \mathrm{mM}\left(\mathrm{NH}_{4}\right)_{2} \mathrm{SO}_{4}, 2 \mathrm{mM} \mathrm{MgCl} 2$, and $75 \mathrm{mM}$ Tris-HCl, pH 9.0). The thermal cycler protocol consisted of an initial cycle at $98^{\circ} \mathrm{C}$ for $3 \mathrm{~min}$, followed by 30 cycles at $96^{\circ} \mathrm{C}$ for $1 \mathrm{~min}, 60^{\circ} \mathrm{C}$ for $1 \mathrm{~min}$, and $72^{\circ} \mathrm{C}$ for $1 \mathrm{~min}$, and a final cycle at $72^{\circ} \mathrm{C}$ for $10 \mathrm{~min}$. Amplification was carried out in a thermal cycler, PTC-200 (MJ Research Inc., Waltham, MA, USA). PCR products were analyzed by $1.5 \%$ agarose gel electrophoresis after ethidium bromide staining.
PCR products were digested with $10 \mathrm{U}$ PvuII, HindIII or HhaI (Amersham Pharmacia Biotech of Brazil) at $37^{\circ} \mathrm{C}$ for $4 \mathrm{~h}$. Restriction fragments were identified by electrophoresis on $2 \%$ agarose gels ( $P v u \mathrm{II}$ and HindIII) and $8 \%$ polyacrylamide gels (HhaI).

Genotypes for LPL and apo E polymorphisms were determined using a homozygous sample for the restriction site as positive control. In addition, $10 \%$ of the analyses were repeated at random.

\section{Statistical analysis}

Data were initially analyzed by descriptive statistics. Categorical variables were compared by the chi-square test and continuous variables were compared by the Student $t$-test for two independent variables. One-way ANOVA was used for comparison between more than two independent variables, that were further evaluated by the Tukey-HSD test for multiple comparisons. One-way repeated measures ANOVA was used to compare the mean serum concentration of lipids in the third trimester of pregnancy and during the puerperium. The level of significance was set at 5\% in all analyses.

\section{Results}

The demographic characteristics and biochemical data of the pregnant women studied are shown in Table 1. Mean gestational age was $34 \pm 3$ weeks and the number of previous pregnancies ranged from 1 to 6 , with a mean of $2 \pm 1$. Most women (53\%) were in their first pregnancy, $22.7 \%$ in the second pregnancy, $18.2 \%$ in the third, and the others had had three or more gestations. The reported weight gain during pregnancy was $10 \pm 5 \mathrm{~kg}$. All women consumed their habitual diet according to Brazilian patterns and none mentioned being a vegetarian. None admitted consuming alcohol during pregnancy but $8 \%$ were smokers. Family history indicated that 40 to $60 \%$ of their parents had 
Table 1. Demographic characteristics and biochemical data of the pregnant women studied.

\begin{tabular}{lc}
\hline Number of subjects & 88 \\
Age (years) & $24.7 \pm 5.0$ \\
Weight (kg) & $70.2 \pm 4.6$ \\
Height (cm) & $160.1 \pm 6.5$ \\
Weight gain (kg) & $10.5 \pm 4.6$ \\
Gestational age (weeks) & $34 \pm 3$ \\
Number of pregnancies & $2 \pm 1$ \\
Family history & \\
$\quad$ Hypertension & $53(60 \%)$ \\
Diabetes mellitus & $43(49 \%)$ \\
Dyslipidemia & $35(40 \%)$ \\
Cerebrovascular disease & $24(27 \%)$ \\
Coronary artery disease & $15(17 \%)$ \\
Smoking & $7(8 \%)$ \\
Plasma glucose (mg/dL) & $75.0 \pm 8.4$ \\
Creatinine (mg/dL) & $0.7 \pm 0.1$ \\
Urea (mg/dL) & $15 \pm 4$ \\
Thyroid-stimulating hormone (mU/L) & $2.3 \pm 1.2$ \\
Aspartate aminotransferase (U/L) & $21 \pm 7$ \\
Alanine aminotransferase (U/L) & $15 \pm 8$ \\
Gamma-glutamyl transpeptidase (U/L) & $14 \pm 7$ \\
Total cholesterol (mg/dL) & $244 \pm 44$ \\
Triglycerides (mg/dL) & $196 \pm 56$ \\
HDL cholesterol (mg/dL) & $68 \pm 14$ \\
LDL cholesterol (mg/dL) & $138 \pm 41$ \\
VLDL cholesterol (mg/dL) & $39 \pm 11$ \\
& \\
&
\end{tabular}

Data are reported as means \pm SD or as number of individuals with percent in parentheses. $\mathrm{HDL}=$ high-density lipoprotein; LDL = low-density lipoprotein; VLDL = very low-density lipoprotein. hypertension, diabetes mellitus, and dyslipidemia, and 27 and $17 \%$ of their relatives had cerebrovascular and coronary artery diseases, respectively.

Analysis of the lipid profile showed an increase in serum total and LDL cholesterol as well as TG compared to reference values (Table 1). Plasma glucose was in the normal range, as also were the biomarkers of thyroid, liver and kidney diseases. The demographic and biochemical results were similar when the pregnant women were divided into groups according to gestational month (data not shown).

Allele frequencies for LPL and apo E SNPs are shown in Table 2. The relative frequencies of the $\mathrm{H} 1$ and $\mathrm{P} 1$ alleles were 0.284 and 0.510 , respectively. Alleles E2, E3 and E4 of the apo E polymorphism had relative frequencies of $0.057,0.841$ and 0.102 , respectively. These allelic frequencies were similar to those found in other Caucasian populations ( $\mathrm{P}>0.05$; Table 2$)$.

In order to evaluate the serum lipid profile of women with different genotypes, we grouped the less common homozygous genotype with the heterozygous genotype for

Table 2. Relative allele frequencies for lipoprotein lipase (LPL) and apolipoprotein $E$ (apo $E$ ) single nucleotide polymorphisms in pregnant women* and other Caucasian populations.

\begin{tabular}{|c|c|c|c|c|c|c|}
\hline & \multirow[t]{2}{*}{$\mathrm{N}$} & \multicolumn{2}{|c|}{ LPL HindIII } & \multicolumn{2}{|c|}{ LPL Pvull } & \multirow[t]{2}{*}{ Reference } \\
\hline & & $\mathrm{H} 1$ & $\mathrm{H} 2$ & $\mathrm{P} 1$ & P2 & \\
\hline Present study & $88^{*}$ & 0.284 & 0.716 & 0.510 & 0.490 & \\
\hline Brazil & 506 & 0.267 & 0.733 & 0.506 & 0.494 & 26 \\
\hline France & 966 & 0.303 & 0.697 & 0.487 & 0.513 & 4 \\
\hline Germany & 649 & 0.289 & 0.711 & 0.490 & 0.510 & 25 \\
\hline USA & 923 & 0.243 & 0.757 & 0.455 & 0.545 & 2 \\
\hline \multirow[t]{3}{*}{ USA } & 168 & 0.286 & 0.714 & 0.417 & 0.583 & 5 \\
\hline & & \multicolumn{3}{|c|}{ apoE Hhal } & & \\
\hline & & E2 & E3 & E4 & & \\
\hline Present study & $88^{*}$ & 0.057 & 0.841 & 0.102 & & \\
\hline Brazil & 100 & 0.080 & 0.810 & 0.110 & & 17 \\
\hline Brazil & 100 & 0.096 & 0.808 & 0.096 & & 27 \\
\hline Belgium & $525^{*}$ & 0.066 & 0.818 & 0.116 & & 30 \\
\hline Italy & 180 & 0.050 & 0.860 & 0.090 & & 21 \\
\hline Portugal & $144^{*}$ & 0.052 & 0.844 & 0.104 & & 29 \\
\hline Canada & $250^{*}$ & 0.076 & 0.814 & 0.110 & & 28 \\
\hline
\end{tabular}


LPL PvuII and HindIII SNPs. For apo E SNP analysis, the women carrying the E4E4 genotype were grouped with the women carrying the E3/E4 genotype (E4 carriers). We excluded two E2E4 genotype carriers because the E2 and E4 alleles have opposite effects. No relations were found between LPL and apo E SNPs and demographic characteristics or a family history of hypertension, diabetes, dyslipidemia, and cardiovascular and cerebrovascular diseases (data not shown).

Women carrying the P1P1 genotype had higher serum LDL cholesterol $(155 \pm 45 \mathrm{mg} /$
$\mathrm{dL}$ ) than women carrying the P1P2/P2P2 genotype $(133 \pm 45 \mathrm{mg} / \mathrm{dL} ; \mathrm{P}=0.032$; Table $3)$. These differences were independent of the demographic variables. A similar serum lipid profile was found among carriers of the LPL-HindIII and apo E-HhaI genotypes (P $>0.05$; Table 3 ).

During the puerperium period, serum TG and VLDL cholesterol levels were significantly reduced in women carrying the P1P1 $(73 \%, \mathrm{P}=0.006)$ and $\mathrm{P} 1 \mathrm{P} 2(51 \%, \mathrm{P}=0.002)$ genotypes but not in $\mathrm{P} 2 \mathrm{P} 2$ carriers $(23 \%, \mathrm{P}>$ 0.05 ; Figure 1). Serum LDL cholesterol was also slightly reduced during the puerperium

\begin{tabular}{|c|c|c|c|c|c|c|}
\hline \multirow[t]{2}{*}{ Polymorphism } & \multirow[t]{2}{*}{ Genotype } & \multicolumn{5}{|c|}{ Lipids (mg/dL) } \\
\hline & & $\mathrm{TC}$ & $\mathrm{TG}$ & $\mathrm{HDL}$ & LDL & VLDL \\
\hline \multirow[t]{3}{*}{ LPL-Pvull } & P1P1 (N = 21) & $258 \pm 55$ & $201 \pm 62$ & $67 \pm 15$ & $155 \pm 45$ & $40 \pm 12$ \\
\hline & $\mathrm{P} 1 \mathrm{P} 2 / \mathrm{P} 2 \mathrm{P} 2(\mathrm{~N}=67)$ & $240 \pm 40$ & $195 \pm 55$ & $69 \pm 14$ & $133 \pm 39$ & $39 \pm 11$ \\
\hline & $\mathrm{pa}$ & 0.115 & 0.668 & 0.552 & 0.032 & 0.717 \\
\hline \multirow[t]{3}{*}{ LPL-HindIII } & $\mathrm{H} 1 \mathrm{H} 1 / \mathrm{H} 1 \mathrm{H} 2(\mathrm{~N}=48)$ & $251 \pm 42$ & $189 \pm 56$ & $70 \pm 15$ & $143 \pm 40$ & $38 \pm 11$ \\
\hline & $\mathrm{H} 2 \mathrm{H} 2(\mathrm{~N}=40)$ & $237 \pm 47$ & $206 \pm 56$ & $67 \pm 13$ & $133 \pm 42$ & $41 \pm 11$ \\
\hline & $\mathrm{pa}$ & 0.146 & 0.162 & 0.405 & 0.292 & 0.245 \\
\hline \multirow[t]{4}{*}{ apoE-Hhal } & E2E3 $(\mathrm{N}=6)$ & $237 \pm 29$ & $221 \pm 79$ & $71 \pm 20$ & $122 \pm 29$ & $44 \pm 16$ \\
\hline & E3E3 $(\mathrm{N}=63)$ & $245 \pm 46$ & $192 \pm 57$ & $70 \pm 14$ & $140 \pm 42$ & $38 \pm 12$ \\
\hline & E3E4 $(\mathrm{N}=17)$ & $244 \pm 39$ & $200 \pm 39$ & $62 \pm 9$ & $142 \pm 40$ & $40 \pm 8$ \\
\hline & $\mathrm{P}^{\mathrm{b}}$ & 0.648 & 0.704 & 0.146 & 0.605 & 0.677 \\
\hline
\end{tabular}

Data are reported as mean $\pm \mathrm{SD}$ and compared by the aStudent $t$-test or bone-way ANOVA. TC = total cholesterol; $\mathrm{TG}=$ triglycerides; $\mathrm{HDL}=$ high-density lipoprotein cholesterol; $\mathrm{LDL}=$ low-density lipoprotein cholesterol; VLDL = very low-density lipoprotein cholesterol.
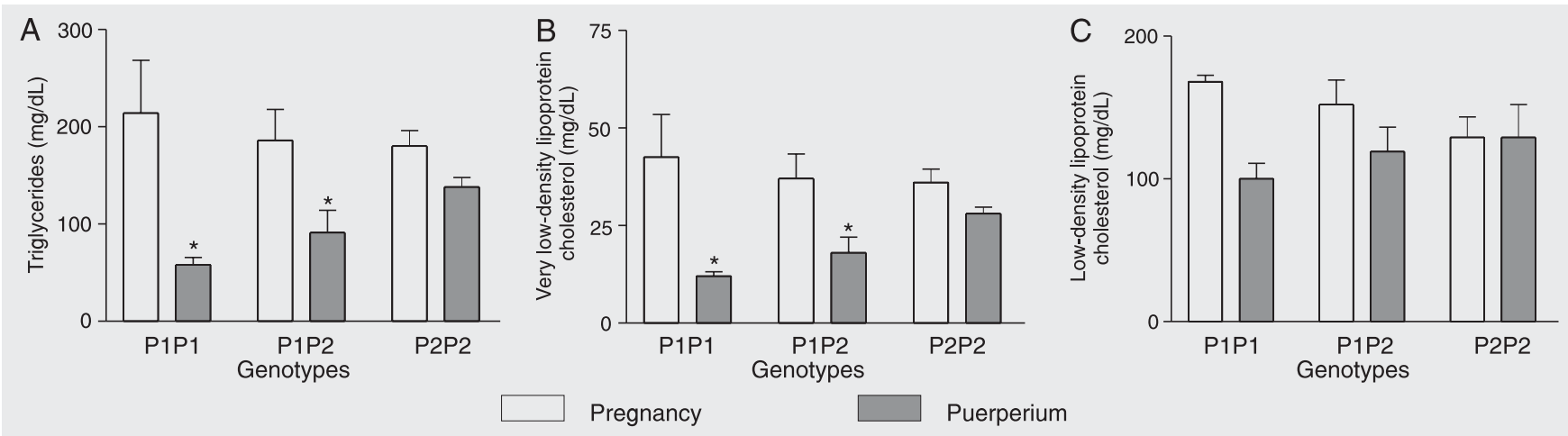

Figure 1. Serum concentration of triglycerides (panel A), very low-density lipoprotein cholesterol (panel B), and low-density lipoprotein cholesterol (panel C) in pregnant women classified according to the LPL-Pvull genotypes. Data are reported as means \pm SEM. ${ }^{*} \mathrm{P}<0.01$ compared to the pregnancy period for the same genotype (one-way repeated measures ANOVA). 
in women carrying the P1P1 $(40 \%, \mathrm{P}=$ $0.051)$ and P1P2 (22\%, P = 0.078) genotypes. The effects of $P v u I I$ polymorphism on serum lipids appeared to be independent of age, weight gain, number of previous pregnancies, and serum lipid concentrations during pregnancy. LDL HindIII and apo E SNPs were not associated with variations in serum lipids during the puerperium period (data not shown).

\section{Discussion}

We selected a group of 88 non-diabetic women of European descent and investigated the relationship of LPL and apo E SNPs with the serum lipid profile during the third trimester of pregnancy. Environmental aspects such as weight gain and dietary habits did not show an effect on the lipid metabolism of pregnant women as reported by others $(9,10)$. Although some longitudinal studies have shown that the serum lipid profile is modified during the last 3 months of pregnancy $(18,19)$, the length of gestation was not associated with variation in serum lipid profile in our study.

The frequency of overweight women in our sample $(37.5 \%)$ was similar to that found in a large sample of pregnant women $(25.0 \%)$ assisted by public health services in 6 Brazilian capital cities (20). Although weight gain during pregnancy has been associated with increased serum TG concentrations (20), no significant relationship was demonstrable between these variables in our sample.

The serum lipid concentrations detected in our study are similar to those found in another study (21) and are representative of what can be expected from a population of healthy pregnant women. The moderate HTG found in the third trimester of pregnancy may be due to the physiological response to the increase in plasma estrogen and progesterone levels $(9,22)$. Increased plasma TG during the third trimester of pregnancy has been correlated with a significant reduction of LPL mass (23), whose gene expression has been shown to be inhibited by estrogen in adipocytes (24).

The frequencies of the $\mathrm{H} 1$ and $\mathrm{P} 2$ alleles of the LPL polymorphisms were similar to those found in non-pregnant Caucasian American (2,5), German (25), and Brazilian women of European ancestry (26). Moreover, the apo $\mathrm{E}$ allelic frequencies in our sample were similar to those detected in non-pregnant Brazilian women of Caucasian descent $(17,27)$ and in pregnant women from other Caucasian populations $(21,28$ 30).

There was a significant association between the LPL P1P1 genotype and increased serum LDL cholesterol levels in pregnant women, possibly contributing to the variation in serum lipids found in women during the third trimester of pregnancy. The PvuII variant has been indicated as a possible marker for a functional mutation that alters LPL activity and interferes with TG and cholesterol metabolism $(31,32)$. It has been shown that the S447X mutation of the LPL gene is associated with variation in serum LDL cholesterol and TG levels of pregnant women $(28,30)$.

Despite the associations between HindIII polymorphism and variations in serum lipids found in other studies $(3,6,26,33,34)$, we could not establish this association in pregnant women. The findings that the $\mathrm{H} 2 \mathrm{H} 2$ genotype is associated with increased TG and reduced HDL cholesterol could be due to the lower activity of LPL in carriers of such genotype $(2,25,34)$. The differences between our results and those obtained by other investigators may be due to the limited size of our sample since approximately $25 \%$ of the pregnant women were excluded. In addition, this caused the statistical power of the test performed to be below the desired level. Therefore, other studies involving larger samples (at least two to three times larger) are necessary to evaluate the relation between LPL polymorphisms and lipid pro- 
file during pregnancy in our population.

Apolipoprotein E variants contribute to up to 10 and $50 \%$ variation in plasma concentrations of total cholesterol and LDL cholesterol, respectively $(27,35,36)$. Belo et al. (29) reported that the apo E genotype is associated with changes in lipid and lipoprotein profiles in pregnant women. In our study, individuals carrying the $\mathrm{E} 4$ allele had a higher LDL/HDL cholesterol ratio than individuals carrying the E3 and E2 alleles, although the differences did not reach statistical significance. The lack of association between apo E SNP and serum TG concentrations was demonstrated in pregnant women with normal glucose tolerance (20).

Other studies have shown that pregnant women carrying the E2 allele have lower concentrations of total and LDL cholesterol than E3 and E4 allele carriers, suggesting that the E2 allele may have a protective cardiovascular effect in pregnancy (28-30). The differences in total cholesterol levels associated with apo E genotypes may have an effect on steroidogenesis and consequently determine the differential fertility that has been observed in Europeans (37).

During the puerperium, serum lipids were significantly reduced, as previously demonstrated in other studies (38-40). Significant reductions in serum TG and VLDL cholesterol levels were found in women carrying the P1P1 and P1P2 genotypes, whereas in $\mathrm{P} 2 \mathrm{P} 2$ genotype carriers the serum levels of these lipids remained increased up to six weeks after delivery. These differences may explain the variability of the physiological response of serum lipids found after delivery in non-diabetic pregnant women (38).

The effects of the $P v u I I$ variant on maternal serum lipids may be due to a possible interaction between PvuII and the S447X mutation or another functional mutation in the LPL gene, as previously shown in pregnant women (28). Moreover, immediately after delivery maternal TG was significantly lower in carriers of the S447X mutation of the LPL gene (30).

The results of our study suggest that $P v$ uII SNP of the LPL gene contribute to the variability in serum lipids during the third trimester of pregnancy and in the puerperium period in non-diabetic women.

\section{Acknowledgments}

We thank the clinicians of the Metropolitan Health Department of São Paulo city for assistance during the selection of the pregnant women included in this study.

\section{References}

1. Mead JR, Irvine SA, Ramji DP. Lipoprotein lipase: structure, function, regulation, and role in disease. $J$ Mol Med 2002; 80: 753-769.

2. Ahn YI, Kamboh MI, Hamman RF, Cole SA, Ferrell RE. Two DNA polymorphisms in the lipoprotein lipase gene and their associations with factors related to cardiovascular disease. J Lipid Res 1993; 34: 421-428.

3. Mitchell RJ, Earl L, Bray P, Fripp YJ, Williams J. DNA polymorphisms at the lipoprotein lipase gene and their association with quantitative variation in plasma high-density lipoproteins and triacylglycerides. Hum Biol 1994; 66: 383-397.

4. Jemaa R, Fumeron F, Poirier O, Lecerf L, Evans A, Arveiler D, et al. Lipoprotein lipase gene polymorphisms: associations with myocardial infarction and lipoprotein levels, the ECTIM study. Etude Cas Témoin sur l'Infarctus du Myocarde. J Lipid Res 1995; 36: 21412146.
5. Anderson JL, King GJ, Bair TL, Elmer SP, Muhlestein JB, Habashi J, et al. Association of lipoprotein lipase gene polymorphisms with coronary artery disease. J Am Coll Cardiol 1999; 33: 1013-1020.

6. Larson I, Hoffmann MM, Ordovas JM, Schaefer EJ, Marz W, Kreuzer J. The lipoprotein lipase HindllI polymorphism: association with total cholesterol and LDL-cholesterol, but not with HDL and triglycerides in 342 females. Clin Chem 1999; 45: 963-968.

7. Pasalic D, Sertic J, Kunovic B, Milicevic Z, Pasic A, Zrinski-Topic R, et al. Lipoprotein lipase gene polymorphism and lipid profile in patients with hypertriglyceridemia. Croat Med J 2001; 42: 517-522.

8. Mahley RW, Rall SC Jr. Apolipoprotein E: far more than a lipid transport protein. Annu Rev Genomics Hum Genet 2000; 1: 507537.

9. Herrera E. Lipid metabolism in pregnancy and its consequences in the fetus and newborn. Endocrine 2002; 19: 43-55. 
10. Di Cianni G, Miccoli R, Volpe L, Lencioni C, Del Prato S. Intermediate metabolism in normal pregnancy and in gestational diabetes. Diabetes Metab Res Rev 2003; 19: 259-270.

11. Suga S, Tamasawa N, Kinpara I, Murakami H, Kasai N, Onuma T, et al. Identification of homozygous lipoprotein lipase gene mutation in a woman with recurrent aggravation of hypertriglyceridaemia induced by pregnancy. J Intern Med 1998; 243: 317-321.

12. Keilson LM, Vary CP, Sprecher DL, Renfrew R. Hyperlipidemia and pancreatitis during pregnancy in two sisters with a mutation in the lipoprotein lipase gene. Ann Intern Med 1996; 124: 425-428.

13. Ma Y, Ooi TC, Liu MS, Zhang H, McPherson R, Edwards AL, et al. High frequency of mutations in the human lipoprotein lipase gene in pregnancy-induced chylomicronemia: possible association with apolipoprotein E2 isoform. J Lipid Res 1994; 35: 1066-1075.

14. Hieronimus $\mathrm{S}$, Benlian $\mathrm{P}$, Bayer $\mathrm{P}$, Bongain A, Fredenrich A. Combination of apolipoprotein E2 and lipoprotein lipase heterozygosity causes severe hypertriglyceridemia during pregnancy. Diabetes Metab 2005; 31: 295-297.

15. Salazar LA, Hirata MH, Cavalli SA, Machado MO, Hirata RD. Optimized procedure for DNA isolation from fresh and cryopreserved clotted human blood useful in clinical molecular testing. Clin Chem 1998; 44: 1748-1750.

16. Regis-Bailly A, Visvikis S, Steinmetz J, Feldmann L, Briancon S, Danchin N, et al. Frequencies of five genetic polymorphisms in coronarographed patients and effects on lipid levels in a supposedly healthy population. Clin Genet 1996; 50: 339-347.

17. Salazar LA, Hirata MH, Giannini SD, Forti N, Diament J, Lima TM, et al. Seven DNA polymorphisms at the candidate genes of atherosclerosis in Brazilian women with angiographically documented coronary artery disease. Clin Chim Acta 2000; 300: 139-149.

18. Sattar N, Greer IA, Louden J, Lindsay G, McConnell M, Shepherd J, et al. Lipoprotein subfraction changes in normal pregnancy: threshold effect of plasma triglyceride on appearance of small, dense low density lipoprotein. J Clin Endocrinol Metab 1997; 82: 2483-2491.

19. Hubel CA, Shakir Y, Gallaher MJ, McLaughlin MK, Roberts JM. Low-density lipoprotein particle size decreases during normal pregnancy in association with triglyceride increases. J Soc Gynecol Investig 1998; 5: 244-250.

20. Nucci LB, Schmidt MI, Duncan BB, Fuchs SC, Fleck ET, Santos Britto MM. Nutritional status of pregnant women: prevalence and associated pregnancy outcomes. Rev Saúde Pública 2001; 35: 502507.

21. Di Cianni G, Miccoli R, Volpe L, Lencioni C, Ghio A, Giovannitti MG, et al. Maternal triglyceride levels and newborn weight in pregnant women with normal glucose tolerance. Diabet Med 2005; 22: 21-25.

22. Mazurkiewicz JC, Watts GF, Warburton FG, Slavin BM, Lowy C, Koukkou E. Serum lipids, lipoproteins and apolipoproteins in pregnant non-diabetic patients. J Clin Pathol 1994; 47: 728-731.

23. Kinoshita T, Shirai K, Itoh M. The level of pre-heparin serum lipoprotein lipase mass at different stages of pregnancy. Clin Chim Acta 2003; 337: 153-156.

24. Homma H, Kurachi H, Nishio Y, Takeda T, Yamamoto T, Adachi K, et al. Estrogen suppresses transcription of lipoprotein lipase gene. Existence of a unique estrogen response element on the lipoprotein lipase promoter. J Biol Chem 2000; 275: 11404-11411.

25. Hallman DM, Groenemeijer BE, Jukema JW, Boerwinkle E, Kastelein JJ. Analysis of lipoprotein lipase haplotypes reveals asso- ciations not apparent from analysis of the constituent loci. Ann Hum Genet 1999; 63: 499-510.

26. Rios DL, Vargas AF, Ewald GM, Torres MR, Zago AJ, CallegariJacques SM, et al. Common variants in the lipoprotein lipase gene in Brazil: association with lipids and angiographically assessed coronary atherosclerosis. Clin Chem Lab Med 2003; 41: 1351-1356.

27. de-Andrade FM, Larrandaburu M, Callegari-Jacques SM, Gastaldo $\mathrm{G}$, Hutz $\mathrm{MH}$. Association of apolipoprotein $\mathrm{E}$ polymorphism with plasma lipids and Alzheimer's disease in a Southern Brazilian population. Braz J Med Biol Res 2000; 33: 529-537.

28. McGladdery SH, Frohlich JJ. Lipoprotein lipase and apoE polymorphisms: relationship to hypertriglyceridemia during pregnancy. $J$ Lipid Res 2001; 42: 1905-1912.

29. Belo L, Gaffney D, Caslake M, Santos-Silva A, Pereira-Leite L, Quintanilha A, et al. Apolipoprotein E and cholesteryl ester transfer protein polymorphisms in normal and preeclamptic pregnancies. Eur J Obstet Gynecol Reprod Biol 2004; 112: 9-15.

30. Descamps OS, Bruniaux M, Guilmot PF, Tonglet R, Heller FR. Lipoprotein concentrations in newborns are associated with allelic variations in their mothers. Atherosclerosis 2004; 172: 287-298.

31. Henderson HE, Kastelein JJ, Zwinderman AH, Gagne E, Jukema JW, Reymer PW, et al. Lipoprotein lipase activity is decreased in a large cohort of patients with coronary artery disease and is associated with changes in lipids and lipoproteins. J Lipid Res 1999; 40: 735-743.

32. Ukkola O, Garenc C, Perusse L, Bergeron J, Despres JP, Rao DC, et al. Genetic variation at the lipoprotein lipase locus and plasma lipoprotein and insulin levels in the Quebec Family Study. Atherosclerosis 2001; 158: 199-206.

33. Holmer SR, Hengstenberg C, Mayer B, Doring A, Lowel H, Engel S, et al. Lipoprotein lipase gene polymorphism, cholesterol subfractions and myocardial infarction in large samples of the general population. Cardiovasc Res 2000; 47: 806-812.

34. Corella D, Guillen M, Saiz C, Portoles O, Sabater A, Folch J, et al. Associations of LPL and APOC3 gene polymorphisms on plasma lipids in a Mediterranean population: interaction with tobacco smoking and the APOE locus. J Lipid Res 2002; 43: 416-427.

35. Eichner JE, Dunn ST, Perveen G, Thompson DM, Stewart KE, Stroehla BC. Apolipoprotein E polymorphism and cardiovascular disease: a HuGE review. Am J Epidemiol 2002; 155: 487-495.

36. Knoblauch $\mathrm{H}$, Bauerfeind A, Toliat MR, Becker C, Luganskaja T, Gunther UP, et al. Haplotypes and SNPs in 13 lipid-relevant genes explain most of the genetic variance in high-density lipoprotein and low-density lipoprotein cholesterol. Hum Mol Genet 2004; 13: 9931004.

37. Corbo RM, Scacchi R, Cresta M. Differential reproductive efficiency associated with common apolipoprotein e alleles in postreproductive-aged subjects. Fertil Steril 2004; 81: 104-107.

38. Koukkou E, Watts GF, Lowy C. Serum lipid, lipoprotein and apolipoprotein changes in gestational diabetes mellitus: a cross-sectional and prospective study. J Clin Pathol 1996; 49: 634-637.

39. Qureshi IA, Xi XR, Pasha N, Zheng HA, Huang YB, Wu XD. Hyperlipidemia of normal pregnancy in Karachi-Pakistan. Kaohsiung $J$ Med Sci 1999; 15: 529-535.

40. Choi JW, Pai SH. Serum lipid concentrations change with serum alkaline phosphatase activity during pregnancy. Ann Clin $\mathrm{Lab} \mathrm{Sci}$ 2000; 30: 422-428. 